Proceedings of the 1st international conference Economic and Business Trends Shaping the Future $\mid 2020$

\title{
THE EXPERIENCE ECONOMY APPROACH - AN EMPIRICAL EXAMINATION IN WINE INDUSTRY
}

\author{
Ezeni Brzovska \\ Faculty of Economics - Skopje, Ss. Cyril and Methodius University \\ ezeni@eccf.ukim.edu.mk \\ Nikolina Palamidovska Sterjadovska \\ Faculty of Economics - Skopje, Ss. Cyril and Methodius University \\ nikolina.palamidovska-sterjadovska@eccf.ukim.edu.mk \\ Đurđana Ozretić Došen \\ Faculty of Economics \& Business, University of Zagreb \\ dozretic@efzg.hr
}

\begin{abstract}
The purpose of this paper is to analyze the four realms of experience economy model (education, entertainment, escapism, and esthetic) and to examine their impact on wine tourists' arousal, memory and loyalty. The experience economy has recently emerged as a relevant framework for understanding the consumers' experience across different industries. Wineries are facing new challenges where tourists are in search for exciting, unique, and memorable experiences. Consequently, wine institutions should strive to create desirable experiential environment as an essential source of differentiation and competitive advantage on the market. Data were collected from online surveys completed by 158 wine tourists in Macedonia. This study employed multiple regression analyses to test the developed hypotheses. The obtained results indicate that there is a significant and positive relationship among education and esthetics as experience dimensions and arousal and memory, separately. The others two experience dimensions are not significantly related neither to arousal, nor to memory. The results also indicate that loyalty is significantly and positively determined by entertainment and negatively influenced by escapism. The obtained results suggest that Macedonian wineries should emphasis the educational and esthetic aspects in their tourist offers in order to improve tourists' arousal and memory. Understanding the concept of experience economy within the wine industry will lead to contemporary applications for all the involved parties.
\end{abstract}

Keywords: experience economy, arousal, memory, loyalty, wine tourism

\section{JEL classification: M31}

\section{INTRODUCTION}

Wine tourism is facing new challenges where tourists are in search for extraordinary, unique and memorable experiences which requires individual wine operators to develop a distinct, engaging and value-added offering. The latest research suggests the need for a more holistic approach to the experiential nature of wine tourism. The growing interest demonstrated by wine tourists has fostered the proliferation of extended wine related activities. Nowadays wine tourism is comprised not solely of wine consumption, but is accompanied by wine tasting in wine cellars, wine festivals or sport activities (Vesela and Malacka, 2015). With the growing awareness and

http://doi.org/10.47063/EBTSF.2020.0037

http://hdl.handle.net/20.500.12188/9706 
interest for wine tourisms visitors are seeking for more authentic and engaging experience, being able to actively participate in various activities.

The experience economy concept suggests that experience is a form of unique economic offering that creates a competitive advantage, which is difficult to be imitated and replaced (Pine and Gilmore, 1999). As mentioned above, experience occurs when a company intentionally uses services to engage individual visitors in a personal and memorable way, improving the significance of experiences of individual satisfaction of each visit. Despite the useful theoretical framework of the experience economy model, empirical examinations on the subject have been scarce (Ali-Knight and Carlsen, 2003; Pikkemaat et al., 2009; Mehmetoglu and Engen, 2011; Quadri-Felitti and Fiore, 2012; Quadri-Felitti and Fiore, 2013). Consequently, this work aims to contribute by empirically examining the experience economy dimensions in the field of wine industry. More specifically, this paper aims to explore a complex combination of four realms of the experience economy in formulating arousal, memories and loyalty among wine visitors. To assess this assumption, we have employed the Pine and Gilmore's experience model (Pine and Gilmore, 2011), and empirically examined the applicability of their concept of an "experience economy" and its four dimensions (education, escapism, esthetics, and entertainment, i.e. 4E).

\section{LITERATURE REVIEW}

Macedonian wine market is characterized by several brands, which makes it harder for consumers to differentiate value propositions. Most wineries are relatively small family businesses, facing the challenges of operating on a small market such as the Macedonian (Simjanovska and Caputo, 2015).

Recognizing that brand is extremely important in wine market where consumers are inundated with plethora of brands and too many choices. Competitive advantage among different offers could be gained and sustained by developing strong brands (Santos and Ribeiro, 2012). Consequently, successful, and strong brands have potential to generate consumer loyalty, as one of the main factors with a positive influence on brand equity (Yoo et al., 2000). Vrontis and Papasolomou (2007) emphasize the importance of branding in wine industry. Creation of memorable experiences that lead to visitors' engagement could improve the whole brand experience.

Visiting a winery comprise a whole set of activities with cultural, food related and historical character. Wine tourism is defined as a visitation to vineyards, wineries, wine festivals and wine shows for tasting the grape characteristic (Hall et al., 1996). Arguing that the motivations and expectations of winery visitors can be quite diverse, Johnson (1998, as cited in Hall et al., 2000, p.5) broaden a wine tourism definition as ,visitation to vineyards, wineries, wine festivals and wine shows for the purpose of recreation." Geißler (2007, as cited in Pikkemaat, 2009) expanded the definition of wine tourism including a wide range of experiences, built around tourist visitation to wineries, wine regions or wine-related events and shows. Hence, wine tourism becomes tourism activity influenced by the physical, social, and cultural dimensions of the winescape and its components (Cambourne et al., 2000). Therefore, the prime motivation factors for visiting a winery are extended to broader set of engaging activities and have become more intentionally experiential. The experience economy is emerging in the context of increasing competition where companies are facing with significant market pressure (Karpov, and Merzlov, 2016).

Wineries need to wisely leverage experience economy and embrace theatre as a model for performance to better meet the needs of specific target group and contribute for promoting future economic prosperity (Pine and Gilmore, 2014). Rethinking the business model of transformations 
with embracing the experience economy, companies can shift from offering mundane services to providing added value experiences (Pine and Gilmore, 2011). Pine and Gilmore (2011) emphasize the urge to employ a whole range of experiences in tourism. Tourists want to enrich their daily lives by experiencing new things and undertaking activities that have entertaining, esthetic, escapist and educational character. Experience providers, in this case wineries, must constantly improve the product experiences, exceeding the consumer needs so they become willing to pay more (Pine and Gilmore, 2011).

New experiences should provide an opportunity to develop new skills and gain new knowledge (Bourdieu, 2000). Visitors benefit from feeling they have experienced something authentic and unique and are willing to share it on social media. As experience-hungry tourists will actively seek enjoyable experience, companies that deliver memorable value beyond basic function of product will be gain better market positions (Yeoman and McMahon-Beattie, 2019).

As the interest in tourist experience has emerged, a plethora of studies have used theories of hedonic and experiential consumer behavior to understand aspects of wine tourism (Williams, 2001; Bruwer and Alant, 2009; Getz and Carlsen, 2008;). Jurowski (2009) proves that different dimensions of tourist participation in specified activities can be grouped in four realms of the experience economy model. Still, studies that have utilized the experience economy framework to wine tourism remains scarce (i.e. Ali-Knight and Carlsen, 2003; Pikkemaat et al., 2009; Mehmetoglu and Engen, 2011; Quadri-Felitti and Fiore, 2012; Quadri-Felitti and Fiore, 2013).

Ali-Knight and Carlsen (2003) emphasized the necessity for staging a memorable and compelling experience in wine industry. Pikkemaat et al. (2009) applied the experience setting model to measure the potential of experience-orientation of South Tyrolean wine routes. The authors emphasize the necessity to create multi-optional attractions and to stage experiences for wine tourists. The four dimensions of the experience realm of Pine and Gilmore were employed for analyzing the expectations and the degree of visitors' satisfaction. Results indicated that esthetic dimension, such as landscape and information about wine, are the most significant regarding visitors' expectations and satisfaction. In terms of expectation, education was noted as a least important dimension, while escape was ranked as lowest concerning visitors' satisfaction (Pikkemaat et al. (2009)

Very few studies empirically tested the 4Es and expanded understanding of the experience economy by examining how tourists' memories operate together with the 4Es and whether satisfaction have influence on their destination loyalty in different tourism settings (QuadriFelitti and Fiore, 2013; Hosany and Witham, 2010; Oh et al., 2007). Four realms of experience offer not only conceptual, but also a practical measurement framework for analyzing the tourist experience. (Quadri-Felitti and Fiore, 2013) measured the experience economy's 4Es by adapting Oh et al.'s (2007) validated 16-item scale and structural equation modeling. The results demonstrated the supremacy of the esthetic experience in predicting positive memories and destination loyalty in the wine tourism context. Hosany and Witham (2010) have employed the four dimensions for understanding cruisers' onboard experiences. Esthetics appeared to be a dominant determinant in predicting satisfaction and intention to recommend. Oh et al. (2007) constructed a measurement scale and empirically tested experience economy conceptual model using customers' lodging experiences with bed-and-breakfasts and the results prove that the esthetic dimension was of high importance of the experiential outcomes. Visitors seek for unique experience among top three reasons in their decision to visit the winery region, after the desire for rest and relaxation in an attractive landscape (Carmichael, 2005). Getz and Carlsen (2008) suggest that wine visitors preferred friendliness, diversity of activities, attractive scenery, knowledgeable staff, and group tours as the main reasons for visiting winery. Mehmetoglu and 
Engen (2011) explore the effects of the experiential dimensions on visitors' satisfaction in different contexts. The findings suggest that experiences need to be developed and modified depending on different contexts. Experiential dimension escapism and esthetics affect the visitor's level of satisfaction for the visitors of the Ice Music Festival, whereas the dimensions of education and aesthetics have significant influence for the Maihaugen Museum. Manthiou et al. (2014) examine the impacts of the experience economy dimensions on festival attendees' vividity of memory and loyalty. The findings reveal the positive effect of the all the experience economy dimensions on vivid memory. The results also indicate that loyalty was affected by the entertainment and esthetics dimensions. Providing satisfactory experience to attendees is the key for the long-term success of festivals (Cole and Illum, 2006). Brzovska et al. (2018) explore the importance of $4 \mathrm{E}$ construct to tourists' evaluations of wine tourism experience and confirm that visitors and wine industry experts perceive esthetic experiences as one of the most significant attributes of the wine touring experience. Olya et al. (2020) employ experience economy model in formulating memories and satisfaction among festival visitors by using augmented reality. The findings reveal that experience economy dimensions through augmented reality can influence visitor satisfaction and the creation of memorable experiences.

Previous studies have shown that implementing the experience economy activities strengthen the consumers' memories. Satisfactory experience is an important motivation for revisiting the place (Andereck and Caldwell, 1993; Tung and Ritchie, 2011). The interest for educational experience is increasing and is becoming one of the main factors for consumers' attendance (Ritchie et al., 2003; Prentice, 2004). Pine and Gilmore (1999) stress the needs for entertainment experiences for having fun and the desire engage in different experiential contexts (i.e. theme parks, theme restaurants) as a way of escaping from their daily routine and revitalizing their lives.

The importance of experience is immensely important, and therefore paper examines which experience dimension significantly influences the visitors' arousal, memory, and loyalty. A desirable experiential environment is an essential source of competitive advantage in the wine industry.

Based on the previous discussions, we focused on the role of arousal, memory, and loyalty, due to the unique context of wine industry. Therefore, the following hypotheses are proposed:

H1a. Education as an experience dimension has positive relationship to arousal

H1b. Entertainment as an experience dimension has positive relationship to arousal

H1c. Escapism as an experience dimension has positive relationship to arousal

H1d. Esthetic as an experience dimension has positive relationship to arousal

H2a. Education as an experience dimension has positive relationship to memory

$\mathrm{H} 2 \mathrm{~b}$. Entertainment as an experience dimension has positive relationship to memory

H2c. Escapism as an experience dimension has positive relationship to memory

$\mathrm{H} 2 \mathrm{~d}$. Esthetic as an experience dimension has positive relationship to memory

H3a. Education as an experience dimension has positive relationship to loyalty

H3b. Entertainment as an experience dimension has positive relationship to loyalty

H3c. Escapism as an experience dimension has positive relationship to loyalty

$\mathrm{H} 3 \mathrm{~d}$. Esthetic as an experience dimension has positive relationship to loyalty

\section{METHODOLOGY}

In this study, Macedonian and foreign tourists, visiting three different Macedonian wineries in the period February to April 2017, were used in the sample. The questionnaire was completed by 
158 respondents. The convenience sampling technique was applied for reaching the respondents. The obtained data were analyzed by applying multiple linear regression, using SPSS.

The survey was consisted of two sections. In the first section a Likert scale was used, measuring the level of agreement with the provided 31 items, ranging from 1 (strongly disagree) to 7 (strongly agree). In this section, the items measuring education (5 items), esthetic (5 items), entertainment (4 items) and escapism (4 items) as experience dimensions were adapted from Manthiou et al. (2014) and Oh et al. (2007). While the items referring to memory (4 items) and arousal (5 items) were developed based on the study of Oh et al. (2007). The loyalty construct (4 items) was measured based on the study of Manthiou et al. (2014).

In the second section, demographic questions were involved. Regarding the demographic characteristics of the sample, respondents are dominantly females $(56.33 \%)$ with average age of 46, ranging from 29 to 65 years. Regarding the level of education, most of the respondents are with an acquired bachelor's degree (49.37\%), followed by a Master degree $(36.08 \%)$.

\section{ANALYSIS AND RESULTS}

\section{Descriptive statistics}

Analyzing the average level of agreement regarding the measured items of the independent and dependent variables, it could be assumed that all the values are below the average (on a scale of 1-strongly disagree to 7-strongly agree). Namely, respondents have perceived education as the most valued experience dimension of winery offers (2.81), while escapism is reported as the least appreciated experience dimension (2.28). Regarding the dependent variables, arousal and memory are also below the average (2.97 and 2.93, respectively), while loyalty has slightly lower values (2.84) (See Table 1).

Table 1. Descriptive statistics

\begin{tabular}{|l|c|c|}
\hline Items & Mean & SD \\
\hline Education & $\mathbf{2 . 8 1}$ & \\
\hline My trip to Macedonian winery made me more knowledgeable & 2.89 & 0.35 \\
\hline I learnt a lot in this winery & 2.88 & 0.36 \\
\hline My trip to Macedonian winery was a real learning experience & 2.83 & 0.44 \\
\hline Visiting winery stimulated my curiosity to learn new things & 2.80 & 0.51 \\
\hline The experience in the winery really enhanced my skills & 2.65 & 0.68 \\
\hline Esthetic & $\mathbf{2 . 7 3}$ & \\
\hline The setting in winery was bland & 1.89 & 0.91 \\
\hline Macedonian winery is very attractive & 2.91 & 0.29 \\
\hline Being in Macedonian winery was very pleasant & 2.96 & 0.21 \\
\hline The setting in winery provided pleasure to my senses & 2.95 & 0.22 \\
\hline I felt a real sense of harmony. during my visit in Macedonian winery & 2.95 & 0.22 \\
\hline Entertainment & $\mathbf{2 . 6 9}$ & \\
\hline I really enjoyed watching what others were doing in Macedonian winery & 2.74 & 0.58 \\
\hline $\begin{array}{l}\text { Activities of others (engaged employees in Macedonian winery) were fun to } \\
\text { watch }\end{array}$ & 2.68 & 0.59 \\
\hline Watching others perform was captivating & 2.61 & 0.64 \\
\hline
\end{tabular}




\begin{tabular}{|l|l|l|}
\hline Activities of others were amusing to watch & 2.72 & 0.60 \\
\hline Escapism & $\mathbf{2 . 2 8}$ & \\
\hline Being in Macedonian winery let me imagine being someone else & 2.47 & 0.79 \\
\hline I completely escaped from reality & 2.29 & 0.85 \\
\hline I felt I played a different character during my visit & 2.20 & 0.90 \\
\hline I felt like I was living in a different time or place & 2.15 & 0.87 \\
\hline Arousal & $\mathbf{2 . 9 7}$ & \\
\hline My visit to the winery was interesting & 2.96 & 0.19 \\
\hline My visit to the winery was enjoyable & 3.00 & 0.00 \\
\hline My visit to the winery was exciting & 2.96 & 0.24 \\
\hline My visit to the winery/these wineries was stimulating for my interest in & 2.96 & 0.26 \\
\hline Macedonian wines & 2.96 & 0.21 \\
\hline My visit to the winery was delighting & $\mathbf{2 . 9 3}$ & \\
\hline Memory & 3.00 & 0.00 \\
\hline I have wonderful memories of this visit to this winery & 2.97 & 0.18 \\
\hline I won't forget my experience visiting this winery & 2.99 & 0.11 \\
\hline I will remember many positive things about this winery & 2.75 & 0.51 \\
\hline This is one of the best wineries I have ever visited & $\mathbf{2 . 8 4}$ & \\
\hline Loyalty & 2.92 & 0.31 \\
\hline I will recommend these winery/ these wineries to others & 2.91 & 0.37 \\
\hline I will encourage others to visit this winery & 2.75 & 0.58 \\
\hline I am willing to visit this winery again & 2.80 & 0.50 \\
\hline I will definitely come back to this destination & & \\
\hline
\end{tabular}

(Source: authors calculations)

\section{Regression analyses}

Three separate regressions were conducted, where education, esthetic, entertainment, and escapism were used as independent variables, while arousal, memory and loyalty were applied as dependent variables, respectively. Below are presented the regression equations, representing each dependent variable as a function of the independent variables, i.e.

$$
\mathrm{I}_{\mathrm{i}}=\beta_{0}+\beta_{1} \mathrm{EE} 1+\beta_{2} \mathrm{EE} 2+\beta_{3} \mathrm{EE} 3+\beta_{4} \mathrm{EE} 4 \quad \text { Equation (1) }
$$

Where,

EE1-education,

EE2-entertainment,

EE3-escapism,

EE4-esthetic,

I1-arousal,

I2-memory,

I3-loyalty 
Regarding the assumptions of the regression, diagnostic tests were conducted (for assessing the normality, linearity and homoscedasticity and no multicollinearity. The conducted diagnostic tests indicated that the models are well specified, but there are certain violations of normality. Regarding that the consequences of this violation are reduction of accuracy of the confidence intervals in predicting a model, this is would not be a strong assumption when the model is used for explanation and not for prediction (Schmidt and Finan, 2018).

The conducted analysis explains $25.4 \%$ of the variations for arousal, while only small proportions of the variations of memory and loyalty are explained (7.8\% and 5.3\%, respectively). All three models were statistically significant. Regression coefficients are presented in tables 2,3 and 4 .

Table 2. Regression results for arousal

\begin{tabular}{|c|c|c|c|}
\hline Variable & $\begin{array}{l}\mathrm{b} \text { (unstandardized } \\
\text { coefficients) }\end{array}$ & $\begin{array}{c}\beta \text { (standardized } \\
\text { coefficients) }\end{array}$ & $\mathrm{T}$ \\
\hline Constant & 3.547 & & 9.575 \\
\hline Education & 0.223 & $0.328 * *$ & 4.387 \\
\hline Esthetic & 0.206 & $0.265 * * *$ & 3.542 \\
\hline Entertainment & 0.062 & 0.113 & 1.363 \\
\hline Escapism & -0.027 & -0.066 & -0.843 \\
\hline Multiple R & 0.523 & & \\
\hline R Square & 0.273 & & \\
\hline $\begin{array}{l}\text { F test statistics, } \\
\text { significance }\end{array}$ & 0.000 & & \\
\hline
\end{tabular}

Notes: Dependent variable is arousal:

$*_{p}<0.05, * * p<0.01, * * * p<0.001$

(Source: authors calculations)

The conducted regression analysis indicates that education and esthetic as experience economy dimensions are significant and positive determinant of arousal, on a significance level of $\mathrm{p}<$ 0.001. The other two dimensions (escapism and esthetic) are not proved to be significant.

Table 3. Regression results for memory

\begin{tabular}{|l|r|r|r|}
\hline \multicolumn{1}{|c|}{ Variable } & $\begin{array}{c}\text { b (unstandardized } \\
\text { coefficients) }\end{array}$ & $\begin{array}{c}\beta \text { (standardized } \\
\text { coefficients) }\end{array}$ & \multicolumn{1}{c|}{$\mathrm{T}$} \\
\hline Constant & 4.505 & & $0.185^{*}$ \\
\hline Education & 0.129 & $0.175^{*}$ & 2.220 \\
\hline Esthetic & 0.140 & 0.076 & 0.102 \\
\hline Entertainment & 0.043 & -0.056 & -0.635 \\
\hline Escapism & -0.023 & & \\
\hline Multiple R & 0.318 & & \\
\hline R Square & 0.101 & & \\
\hline $\begin{array}{l}\text { F test statistics, } \\
\text { significance }\end{array}$ & 0.002 & & \\
\hline
\end{tabular}

Notes: Dependent variable is memory:

$* p<0.05, * * p<0.01, * * * p<0.001$

(Source: authors calculations) 
Memory is also significantly and positively determined by education and esthetic as experience economy dimensions, on a significance level of 0.05 .

Table 4. Regression results for loyalty

\begin{tabular}{|l|r|r|r|}
\hline Variable & $\begin{array}{c}\text { b (unstandardized } \\
\text { coefficients) }\end{array}$ & $\begin{array}{c}\beta \text { (standardized } \\
\text { coefficients) }\end{array}$ & \multicolumn{1}{c|}{$\mathrm{t}$} \\
\hline Constant & 4.641 & 0.035 & 0.221 \\
\hline Education & 0.037 & 0.092 & 1.094 \\
\hline Esthetic & 0.110 & $-0.244^{* *}$ & 2.620 \\
\hline Entertainment & 0.207 & & -2.329 \\
\hline Escapism & -0.130 & & \\
\hline Multiple R & 0.277 & & \\
\hline R Square & 0.077 & & \\
\hline $\begin{array}{l}\text { F test statistics. } \\
\text { significance }\end{array}$ & 0.015 & & \\
\hline
\end{tabular}

Notes: Dependent variable is loyalty:

${ }^{*} p<0.05, * * p<0.01, * * * p<0.001$

(Source: authors calculations)

The conducted regression analysis of loyalty indicates that entertainment and escapism are significant influencers of loyalty, on a significant level of 0.01 and 0.05 , respectively. In this regression model controversial results are obtained regarding the escapism dimension which has significant but negative impact on loyalty. Contrary to arousal and memory, education and esthetic are not significant predictors of loyalty.

\section{DISCUSSIONS}

Employing experience economy model is of utmost importance in the context of highly competitive wine market and offers sustainable competitive advantages. Therefore, wine brand managers should strive to develop relevant and memorable experiences to elicit and capture visitors' attention, increasing the level of interest for wineries among visitors (Mitchell et al., 2000).

In this paper experience economy dimensions are analyzed as predictors of tourists' arousal, memory, and loyalty. Wine tourists are faced with immersion experience during their visit in wineries. Certain experience economy factors may have greater influence on visitor engagement. The finding reveals complex influence and interrelations among esthetics, education, entertainment, and escapism experience on visitor perception. The results demonstrate that different experiential dimensions influence the visitors' overall arousal, memory, and loyalty in different contexts. For instance, while the dimension of education and esthetic has a significant effect on the visitors' arousal and memory, loyalty is significantly associated with entertainment. Escapism was the only dimension with a negative impact on loyalty. Therefore, education and esthetics are experience aspects which should be incorporated in winery touristic offers to increase customers' arousal and to stimulate their long-term memory. On the other hand, tourists will intent to revisit the winery and recommend the winery to their close ones because of experienced entertainment aspect of the visit. 
Consumers are becoming more aware about their preferences and wineries should increase attention to extend the offerings by adding memorable experience. Employing the experience economy approach to the management of the wineries can provide a new impetus to the development of new activities to the visitors. The transition to the experience economy requires the formation of a more holistic product experience. Significant change in the current offers needs to be established to improve the experience, affecting the emotions of the wine visitor. Consumers need and demand new aspects of individual wine visit, willing to pay a high price for memorable experiences (Udviklingsråd, 2005). The delivery of experiences and unique added value for winery visitors will be of increasing importance in the future (Cambourne et al., 2000). Management at wine industries should strive to obtain memorable experiences by creating authentic, multi-sensory and engaging offers eliciting the visitors' attention. Visitors satisfaction derived from multiple experiences will generate positive brand associations and greater loyalty. Developing an educational activity for visitors, creating the attractive design and appealing atmosphere of wineries, providing the entertainment and escapist experience offers new opportunities for enhancing visitor experiences and should be an investment priority for Macedonian wineries.

This study has several limitations that the authors would like to address. First, a non-probability sample is applied which limits the generalization of the results. Also, the cross-country analysis could be performed. The sample investigated in the study involved only visitors form three wineries. To validate the findings in this study, future research should be directed toward larger, more diverse samples. Second, a simultaneous model testing should be conducted in future, comprising the relationships among the latent variables, i.e. the four experience economy dimensions (education. entertainment. escapism and esthetic), arousal, memory and loyalty. Consequently, structural equation modelling should be applied in future studies. Also, some other variables could be involved in the research model.

\section{REFERENCES}

Ali-Knight, J. and Charters, S. (2001), "The winery as educator: Do wineries provide what the wine tourist needs", Australian and New Zealand Wine Industry Journal, Vol. 16 No.6, pp. 7986.

Ali-Knight, J., Carlsen, J. (2003), "An exploration of the use of 'extraordinary'experiences in wine tourism”, in Lockshin, L., Rungie, C. (Eds.) Proceedings of the International Colloquium in Wine Marketing, Wine Marketing Group, University of South Australia, Adelaide, pp. 26-27.

Andereck KL, and Caldwell LL (1993), "The Influence of Tourists' Characteristics on Ratings of Information Sources for an Attraction", Journal of Travel \& Tourism Marketing , Vol. 2 No.3, pp. 171-189.

Bourdieu, P. (2000), Distinction: A Social Critique of the Judgement of Taste, Harvard University Press, Cambridge.

Bruwer, J. and Alant, K. (2009), "The hedonic nature of wine tourism consumption: an experiential view", International Journal of Wine Business Research, Vol. 21 No. 3, pp. 235-257. Brzovska, E., Došen, Đ. O., \& Simjanovska, I. (2018). The importance of different dimensions in the experiential based model among wine tourists and wine industry experts in the Republic of Macedonia. Ekonomski Vjesnik, 31(1), 137-147.

Cambourne, B., Johnson G., Macionis, N., Mitchell, R. and Sharples, L.(2000), "The maturing wine tourism product: an international overview", in Hall, C. M., Sharples, L., Cambourne, B., Macionis, N. (Eds.), Wine Tourism Around the World:Development, Management and Markets, Elsevier Butterworth-Heinemann, Oxford, pp. 24-66. 
Cambourne, B., Johnson G., Macionis, N., Mitchell, R. and Sharples, L.(2000), "The maturing wine tourism product: an international overview", in Hall, C. M., Sharples, L., Cambourne, B., Macionis, N. (Eds.), Wine Tourism Around the World:Development, Management and Markets, Elsevier Butterworth-Heinemann, Oxford, pp. 24-66.

Carmichael, B. (2005), "Understanding the wine tourism experience for winery visitors in the Niagara Region, Ontario, Canada", Tourism Geographies, Vol. 7 No. 2, pp. 185-204.

Cole, S. T., and Illum, S. F. (2006), "Examining the mediating role of festival visitors' satisfaction in the relationship between service quality and behavioral intentions", Journal of Vacation Marketing, Vol.12 No. 2, pp.160-173.

Geißler, R. (2007), "Weininteressierte und ihr Reiseverhalten" [Wine interested consumers and their travel behavior], Diploma thesis.Innsbruck: University of Innsbruck -as cited in Pikkemaat, B., Peters, M., Boksberger, P., Secco, M. (2009), "The staging of experiences in wine tourism", Journal of Hospitality Marketing and Management, Vol.18 No. 2-3, pp.237253.

Getz, D. and Carlsen, J. (2008), "Wine tourism among Generations X and Y", Tourism: An International Interdisciplinary Journal, Vol. 56 No. 3, pp. 257-269.

Hall, C.M. (1996), "Wine tourism in New Zealand",in Higham, J. (Ed.), Proceedings of Tourism Down Under II: A Tourism Research Conference, University of Otago, Dunedin, pp. 109-19.

Hosany, S., Witham, M. (2010), “Dimensions of cruisers' experiences, satisfaction, and intention to recommend", Journal of Travel Research, Vol. 49, No. 3, pp. 51-364.

Hovedstadens Udviklingsråd (HUR). (2005), "Opplevelsesøkonomi i Hovedstadregionen. Utarbeidet av Rambøll Management'[Experience economy in the capital region: Prepared by Rambøll Management]. Available at www.rambollmanagement.dk.

Johnson, G. (1998), "Wine tourism in New Zealand-a national survey of wineries", Unpublished Dip. Tour. Dissertation. Dunedin: University of Otago - as cited in Wine tourism: An introduction, in Hall, C. M., Sharples, L., Cambourne, B. and Macionis, N. (Eds.), Wine Tourism Around the World:Development, Management and Markets, Elsevier Butterworth-Heinemann, Oxford, p. 5.

Jurowski, C. (2009), "An examination of the four realms of tourism experience theory", International CHRIE Conference Refereed Track,Paper 23, Amherst, MA.

Karpov, A., and Merzlov, A. (2016), "The experience economy approach to marketing Les Plus Beaux Villages brand in Russia", Worldwide Hospitality and Tourism Themes, Vol. 8 No. 3, pp. 373-379.

Manthiou, A., Lee, S. A., Tang, L. R., and Chiang, L. (2014), "The experience economy approach to festival marketing: Vivid memory and attendee loyalty" Journal of Services Marketing, Vol. 28 No. 1, pp. 22-35.

Mehmetoglu, M. and Engen, M. (2011), "Pine and Gilmore's concept of experience economy and its dimensions: an empirical examination in tourism", Journal of Quality Assurance in Hospitality and Tourism, Vol. 12 No. 4, pp. 237-255.

Mitchell, R., Hall, M. and Macionis, A. (2000), "Wine tourism and consumer behavior",in Hall, C. M., Sharples, L., Cambourne, B., Macionis, N. (Eds.), Wine Tourism Around the World:Development, Management and Markets, Elsevier Butterworth-Heinemann, Oxford, pp. 297-320.

Oh, H., Fiore, A. M. and Jeoung, M. (2007), "Measuring experience economy concepts: Tourism application", Journal of Travel Research, Vol. 46, No.2, pp. 119-132. 
Olya, H., Jung, T. H., Dieck, M. C. T., and Ryu, K. (2020), "Engaging visitors of science festivals using augmented reality: asymmetrical modelling", International Journal of Contemporary Hospitality Management, Vol. 32 No. 2, pp. 769-796.

Pikkemaat, B., Peters, M., Boksberger, P. and Secco, M. (2009), "The staging of experiences in wine tourism", Journal of Hospitality Marketing and Management, Vol. 18 No. 2-3, pp.237-253.

Pine II, B., and Gilmore, J. H. (2014), "A leader's guide to innovation in the experience economy", Strategy and Leadership, Vol.42 No.1, pp.24-29.

Pine, B. J., Gilmore, J. H. (1999), The Experience Economy: Work Is Theatre \& Every Business a Stage, Boston, MA: Harvard Business Press.

Pine, B. J., Gilmore, J. H. (2011), The Experience Economy, Boston, MA: Harvard Business Press.

Prentice, R. C. (2004), Tourist Motivation and Typologies, In A Companion to Tourism, edited by A. Lew, M. Hall, and A. M. Williams. Oxford: Pergamon, pp. 261-79.

Quadri-Felitti, D. L., Fiore, A. M. (2013), "Destination loyalty: Effects of wine tourists' experiences, memories, and satisfaction on intentions", Tourism and Hospitality Research, Vol. 13 No. 1, pp. 47-62.

Quadri-Felitti, D., Fiore, A. M. (2012), "Experience economy constructs as a framework for understanding wine tourism", Journal of Vacation Marketing, Vol.18 No. 1, pp. 3-15.

Ritchie, B. W., Carr, N., and Cooper, C. P. (2003). Managing educational tourism, Channel View Publications.

Santos, J. F., and Ribeiro, J. C. (2012), "The Portuguese online wine buying consumer", EuroMed Journal of Business, Vol. 7 No. 3, pp. 294-311.

Schmidt, A.F. and Finan, C. (2018), "Linear regression and the normality assumption", Journal of Clinical Epidemiology, Vol. 98, pp. 146-151.

Simjanovska, I., Caputo, (2015), Guide to the Wines of the Republic of Macedonia.

Tung, V. W. S., and Ritchie, J. B. (2011), "Exploring the essence of memorable tourism experiences", Annals of tourism research, Vol.38 No.4, pp. 1367-1386.

Vesela, J., and Malačka, L. (2015), "Use of the wine tourism in the region development: the comparative study", Dokbat - International Bata Conference.

Vrontis, D., and Papasolomou, I. (2007), "Brand and product building: the case of the Cyprus wine industry", Journal of Product and Brand Management, Vol. 16 No. 3, pp. 159-167.

Williams, P. (2001), "Positioning wine tourism destinations: An image analysis", International Journal of Wine Marketing, Vol. 13 No. 3, pp. 42-58.

Yeoman, I. S., and McMahon-Beattie, U. (2019), "The experience economy: micro trend", Journal of Tourism Futures, Vol. 5 No. 2, pp. 114-119.

Yoo, B., Donthu, N., and Lee, S. (2000), "An examination of selected marketing mix elements and brand equity", Journal of the academy of marketing science, Vol.28 No. 2, pp.195-211. 